\title{
The Construction of College Teacher Education and Teaching Ability Under the Innovation and Entrepreneurship Education*
}

\author{
Ying Sheng \\ Xi'an University \\ Xi'an, China 710062
}

\begin{abstract}
The improvement of the innovation and entrepreneurship ability of college teachers is the critical factor for colleges to deepen the concept of innovation-driven development. In order to enhance the ability of innovation, this paper starts from the three aspects of concept, educational technology and classroom teaching. By updating the concept of innovation and entrepreneurship, the application of educational technology can be enhanced; classroom teaching methods can be enriched; teaching and research teams can be integrated, and the teaching and education ability of college teachers can be enhanced.
\end{abstract}

Keywords-college teachers; innovation and entrepreneurship; education and teaching; capability building

\section{INTRODUCTION}

In May 2015, the State Council issued the "Implementation Opinions of the General Office of the State Council on Deepening the Reform of Innovation and Entrepreneurship Education in Colleges and Universities" ( the General Office of the State Council Issue [2015] No. 36). In July 2017, "the State Council's opinion on strengthening the implementation of the innovation-driven development strategy to further promote the in-depth development of mass entrepreneurship and innovation" (the State Council Issue [2017] No. 37) emphasizes the integration of the concept of innovation and entrepreneurship education into the whole process of college education, and enhances the awareness and ability of college teachers to carry out innovation and entrepreneurship education. Therefore, it is necessary to accurately grasp the essential connotation of innovation and entrepreneurship education, creatively enhance the professional competence of college teachers, and carry out the concept of dual-creation education throughout the education and teaching work, realize the close integration of innovation and entrepreneurship education and classroom teaching,

*Fund: General Project of Social Science Fund of Shaanxi Province: Research on the Interactive Mode of Innovation and Entrepreneurship Education and the Development of Professional Ability of College Teachers in Shaanxi (Code: 2017P008), The 13th Five-Year Plan for Education Science in Shaanxi Province in 2017: A Study on the Enhancement of Innovation and Entrepreneurship Education Awareness and Ability of Young Teachers in Colleges and Universities in Shaanxi Province (Code:SGH17H234) comprehensively improve the quality of education and teaching, and improve personnel training ability.

Innovative entrepreneurship education combines the transfer of professional knowledge with the concept of entrepreneurship. It not only pays attention to the cultivation of professional knowledge and ability, but also takes into account the innovation, pioneering and practical nature of talents. To build such a benign educational cycle system, a high-quality, high-level faculty team has become critical. How to integrate the concept of innovation and entrepreneurship in education and teaching has become an urgent problem to be solved.

Importance of improvement of education and teaching ability of college teachers

\section{A. The Improvement of Teacher Education and Teaching Ability Is a Crucial Factor for the Country to Deepen Innovation and Entrepreneurship Education}

The "Implementation Opinions of the General Office of the State Council on Deepening the Reform of Innovation and Entrepreneurship Education in Colleges and Universities" clearly states that "the concept of innovation and entrepreneurship education lags behind. It is not tightly integrated with professional education, and is out of touch with practice." Therefore, the combination of entrepreneurship education and subject education has become the only way for colleges and universities, and it also puts higher demands on college teachers. While continuously improving the professional theoretical knowledge, college teachers must update their concepts and advance with the times, explore the teaching concepts and innovation consciousness that are suitable for the current era of innovation in the education and teaching, optimize professional skills, improve teaching methods, and improve teaching effects. They also must cultivate innovative and entrepreneurial talents with innovative concepts, pioneering spirits and practical behaviors that are suitable for economic development needs. 
B. The Improvement of College Teachers' Education and Teaching Ability Is the Fundamental Guarantee for Colleges and Universities to Embark on Innovative and Sustainable Development

The "Implementation Opinions of the General Office of the State Council on Deepening the Reform of Innovation and Entrepreneurship Education in Colleges and Universities" pointed out that "the reform of innovation and entrepreneurship education in universities should be deepened as a breakthrough to promote comprehensive reform of higher education." Therefore, the comprehensive improvement of the concept of innovation and entrepreneurship in colleges and universities has become a new requirement for colleges and universities in the new era. "The countries of the world have reformed higher education, actively integrated the idea of absorbing innovation and entrepreneurship education, taken innovation and entrepreneurship education as the entry point, and driven the entire higher education, including courses, teaching teachers, personnel training, university management, evaluation and funding mechanisms. Change has become a positive trend of reform".[1]College teachers must adapt to the new requirements of reform and development, update educational concepts, promote team research, reform curriculum teaching methods, strengthen self-learning ability, update evaluation system. They must also cultivate responsible, innovative and entrepreneurial spirit, and solid theoretical knowledge, internationalized and highly qualified talents with sufficient practical skills and pioneering spirit for the development of the new era society.

\section{The Improvement of College Teachers' Education and} Teaching Ability Is the Central Link in the Cultivation of Innovative and Entrepreneurial Talents in Colleges and Universities

"The educational and teaching ability of college teachers is an important criterion for measuring their quality and professional level."[2] In the "Implementation Opinions on Deepening the Reform of Innovation and Entrepreneurship Education in Colleges and Universities", the Ministry of Education will establish a system of innovative and entrepreneurial education in universities that will improve classroom teaching, independent learning, combined practice, guidance and assistance, and cultural integration, and take it as the overall goal of talent training in the new era. Therefore, to achieve the internationalization of college teachers' professional knowledge, the efficiency of scientific and technological achievements transformation, the diversity of teaching methods, evaluation systems, and the innovation of practical skills are to cultivate high-quality talents with innovative ideas, innovative ideas and innovative consciousness. It is also an important link to realize the country's demand for talents in the new era.

\section{The Status Quo of College Teachers' Teaching AND TEACHING ABILITY}

\section{A. Lack of Understanding of Colleges and Universities}

With the rapid development of the economy, the demand for international innovation and entrepreneurial talents has gradually increased. However, at present, some college teachers are limited to "academicization and specialization", and believe that innovation and entrepreneurship are only the needs of a very small number of students, narrowing the concept of innovation and entrepreneurship. "The 'entrepreneurial type' here is not just a simple adjective, but internalized into a kind of spirit and temperament, becoming the prescriptive nature of all kinds of talents."[1]The innovative and entrepreneurial talent represented here means that whether you are starting a business or not, you must have the spirit of innovation and creativity. Under the new educational concept and mode of innovation and entrepreneurship, it is impossible to cultivate a pioneering new talent in the new era based on traditional and simple knowledge transfer and teaching style. The times are progressing and the society is developing. Only by constantly updating teaching concepts, enriching professional knowledge, improving practical research capabilities, improving teaching methods, and optimizing the teaching environment can we improve the overall education and teaching level of colleges and universities and achieve the goal of cultivating innovative talents.

\section{B. Lack of Systematic Integration of Teacher Education and Teaching Skills Training}

Teacher education skills training refer not only to the training of professional technology, but also the application of educational technology. In the actual operation, most colleges and universities do not carry out targeted training according to the actual education and teaching situation of teachers. Instead, they routinely focus their teachers' professional and technical training on teachers' moral concepts and academic research. Training on educational technology is only simple network technology and mutual copying between different professions has the characteristics of lack of pertinence, system, effectiveness and practicality. At the same time, after the professional skills training, there is no effective professional teacher team to disseminate training information, exchange and check for vacancies. Education and teaching training is only in the level of form, and there is no systematic teacher training file afterwards. There is no systematic integration of training content, training objectives and training effects, which greatly reduces the quality of training.

\section{Lack of Independent Innovation Ability in Classroom Teaching}

The strength of teachers' classroom education and teaching ability directly affects the quality of college education and the level of talent training. The "undergraduate teaching project" implemented in China is aimed at talent training. In recent years, some teachers in colleges and universities have followed the rules, adhered to the 
traditional concept of teachers, students, and education. They have insufficient understanding of the development of education and the new Internet plus educational concept. The teaching method is single and only acts as a classroom teaching. They only play the role of "knowledge imparter" but ignores the role of "psychological regulators, researchers, collaborators, listeners..." At the same time, there are problems in education and teaching: lack of systematic and innovative teaching design and organization management and lack of reflection and discussion. In the classroom, the subjective initiative of students has not been mobilized, and there is no systematic and individualized development path in education and teaching, which directly affects the cultivation of innovative and international talents.

\section{THE CONSTRUCTION OF COLLEGE TEACHERS' EDUCATION AND TEACHING ABILITY}

The ability of college teachers' education and teaching is directly related to the quality of talents training. Therefore, we construct from several aspects such as updating concepts, improving the application of educational information, enriching classroom teaching methods, and integrating teaching and research teams.

\section{A. Renewing Concepts and Developing Innovative Entrepreneurial Thoughts}

First of all, the ultimate goal of renewing education concepts and developing entrepreneurial thoughts is to improve the quality of talents training. "The students' innovative spirit, entrepreneurial awareness and innovative entrepreneurial ability have been significantly enhanced," said the General Office of the State Council on deepening the implementation of reforms in innovation and entrepreneurship education in higher education institutions. "And it is pointed out that all regions and universities must put the reform of innovation and entrepreneurship education in colleges and universities as an important task of 'cultivating people and cultivating people' ". Therefore, establishing the concept of innovation and entrepreneurship training is the key factor in the reform of higher education teaching in today's society. Only teachers realize that the improvement of education and teaching ability is directly related to the quality of talent training, can they truly participate in education and teaching.

We also need to break the traditional teaching thinking, change the mindset, enrich the teaching content, reform the teaching methods, establish critical thinking, create a teaching atmosphere of "questioning, exploring and innovating", and stimulate the creative passion of teachers. As Conant, former president of Harvard University said: "The reputation of the university is not in its school buildings and the numbers of people, it is the quality of teachers generation by generation. The teachers of the school must be outstanding if a school wants to be tenable."[3]Therefore, on the basis of "good ideological and political moral cultivation, teaching and educating people, selfless dedication", we will establish a new concept of teacher education, be brave in innovation, continue to explore, adhere to the spirit of pioneering, practice and innovation, and establish a personalized and innovative teaching mechanism. Guide the practical teaching with the new concept of innovation and entrepreneurship.

\section{B. Strengthening Training and Enhancing the Application of Educational Technology}

In September 2010, the National College Educational Technology Coordination Committee issued the "National College Teacher Education Technology Competency Guide". This "National College Teacher Education Technology Competency Guide" raised the overall requirements of strengthening some abilities of college teachers including the understanding on the teaching reform and innovative talent training supported by information technology tools, the awareness of applying educational technology effectively, the ability to effectively apply technical tools, and the ability to use scientific tools to conduct research and teaching. [4]It is of great significance to "improve the teaching quality, optimize the teaching process" and cultivates "innovative talents". Therefore, improving the application ability of teachers' educational information through training is an important factor to improve teachers' educational ability. The priority is to ensure the innovation and practicality of educational technology. The application of educational technology is not only the simple copying of information technology, but also the better way to stimulate the creative potential of learners. Therefore, in practical applications, the training of information technology should be closely integrated with professional theory and practical knowledge, grasp the characteristics of the subject, combine the professional nature, create a personalized teaching design, and realize the innovation and practicality of educational technology. Then what we need to do is to ensure the effectiveness and long-term nature of educational technology. The application of educational technology can effectively improve the quality of education and teaching.

In the actual training process, firstly, the regular, popular online course design, network communication and discussion will be trained uniformly. Secondly, according to the teacher's own characteristics and subject background, targeted guidance should be carried out to gradually enhance the teacher's online curriculum design ability. Thirdly, in the training, discussion sessions should be added in and other teachers can be under the classification guidance of teachers with good information technology applications. Then, after the training, advanced educational information technology is applied to teaching practice to realize the effectiveness and long-term nature of educational technology. Finally, ensure the applicability and operability of educational technology. Through training, the ability to integrate education and teaching resources is continuously improved. In addition to sharing some conventional resources in teaching design, it is necessary to enhance operational ability in classroom practice and apply various techniques to increase the fun and innovation of classroom teaching. We also need to stimulate students' self-learning interests, provide a learning platform for cooperation, communication, and interaction for students, and make this learning form normalized. 


\section{Innovating Thoughts and Enriching Classroom Teaching Methods}

The wide application of new media and new technologies will inevitably lead to the improvement of classroom education and teaching methods. On the basis of traditional teaching methods, Internet plus collaborative teaching will promote the enrichment of teaching methods. There are three main factors affecting the application of teaching methods: teaching content, teaching process, and the educated.

Firstly, according to different teaching content, design teaching methods that conform to the characteristics of the subject, promote the flexible application of MOOC, microclass, flip classroom, and sub-classroom teaching. Under the guidance of the "teacher-led, student-centered" educational philosophy, the flexibility, innovation, adaptability and diversity of teaching methods will be reflected in practical education.

Secondly, different teaching methods in the process of education and teaching need to be applied. The teaching process is not an isolated cognitive activity. The essence is to achieve the integration of the teacher's "teaching" and the student's "study". Therefore, in teaching, we can make good use of the advantages of smart classrooms, using network collaborative teaching methods, applying advanced modern Information technology attracts students to better guide students, stimulate students' sense of innovation and innovative thinking, so that we can cultivate high-quality talents for the country.

Finally, different teaching methods need to be used depending on the different physical and mental characteristics of the educated. The differences in the subject and grade of the educated make the teaching methods for them are different. From the first year of college to the forth, from the first year of graduate to the third, due to the changing living environment and the changing learning environment of the students, the differences in the cognitive ability of the subject and the satisfaction of classroom teaching will constantly change. Therefore, we should constantly improve teachers' classroom self-reflection ability, enrich teaching methods, and cultivate students' innovative learning ability.

\section{Optimizing Resources and Integrating Teaching and Research Teams}

Improving the ability of education and teaching is inseparable from scientific research. "Teaching with scientific research and promoting teaching with scientific research" has become the basic requirement for teachers in contemporary universities. The "Opinions of the General Office of the State Council on Deepening the Reform of Innovation and Entrepreneurship Education in Colleges and Universities" pointed out that "Universities should extensively carry out heuristic, discussion and participatory teaching, expand the coverage of small class teaching, and promote teachers to integrate international cutting-edge academic development, latest research results and practical experience into classroom teaching, focusing on cultivating students' critical and creative thinking to motivate innovation and entrepreneurial inspiration."

First of all, teaching is the dissemination of scientific research. Through teaching, on the one hand, we understand professional knowledge, as well as the basic viewpoints of academic theory. We generate doubts, discover problems, collect information, and find innovative points in scientific research. On the other hand, the most cutting-edge scientific research results are transformed into knowledge applied to education and teaching, and the quality of teaching is improved.

Secondly, scientific research is the promotion of teaching. Through scientific research, we can understand the latest scientific research trends of the subject apply new theories, new thoughts, new changes to guide teachers, update concepts, and enhance teachers' exploration awareness and innovative spirit in teaching. Under the constant innovation, make the teaching foster innovative and entrepreneurial talents that adapt to social development.

Last but not least, through the mentor system, establish a team of teaching and research. Integrate experienced teachers, young teachers and capable students from the same research direction into one team, use the scientific research construction platform to enhance the academic advantages, create forward-looking scientific research results, and truly realize the all-round improvement of teachers' educational capabilities.

\section{CONCLUSION}

The formation of college students' innovative consciousness and innovative thought is inseparable from the improvement of the professional ability of college teachers. To encourage entrepreneurial ability, master entrepreneurial knowledge, establish new ideas and models for innovation and entrepreneurship education, and further deepen the comprehensive reform of higher education in Shaanxi is not only conducive to cultivating new talents with innovative entrepreneurial spirit, but also has certain practical significance for Shaanxi to implement the national innovation-driven development strategy.

\section{REFERENCES}

[1] Wang Zhanren, Controversy and reflection on the comprehensive promotion of innovation and entrepreneurship education in colleges and universities [J] Exploring Education Development 2015. 13-14 ( in Chinese)

[2] Li Gui'an, Li Tiesheng, Dang Huaixing, The Development of College Teachers' Teaching and Teaching Ability and the Innovation of Classroom Teaching Model [J]. China University Teaching 2012, (6) ( in Chinese)

[3] Wang Jingwei et al. Thoughts on the Ways of Training Teachers' Teaching Ability in Colleges and Universities [J] Journal of Heilongjiang Vocational Institute of Ecological Engineering, 2012. (1) ( in Chinese)

[4] Sang Yu, Zhang Zhonghua, Investigation and Research on the Status Quo of University Young Teachers' Information Technology Quality [J] Journal of Jimei University 2014, (10) ( in Chinese) 